\title{
Yolanda of Flanders: Latin Woman Potentate of the Roman Empire
}

\author{
Valentine J. Belfiglio \\ Department of History and Government, Texas Woman's University, Denton, USA \\ Email: vbelfiglio@twu.edu
}

How to cite this paper: Belfiglio, V. J. (2018). Yolanda of Flanders: Latin Woman Potentate of the Roman Empire. Advances in Historical Studies, 7, 22-29. https://doi.org/10.4236/ahs.2018.71003

Received: February 24, 2018

Accepted: March 25, 2018

Published: March 28, 2018

Copyright (C) 2018 by author and Scientific Research Publishing Inc. This work is licensed under the Creative Commons Attribution International License (CC BY 4.0).

http://creativecommons.org/licenses/by/4.0/

\begin{abstract}
The main purpose of this paper is to construct a personality profile of Yolanda, a Latin woman potentate of the Eastern Roman Empire. The key question the author is addressing is whether or not the personality profile of Yolanda can serve as a guide to the personality traits of modern women as political leaders. The most important information in this article is the influence of family, religion, schooling, class, status, experiences, and social contacts upon the psychological development of Yolanda. The main inference in this paper is that there may be similar attributes and circumstances that facilitate the election of women to chiefs-of-state in modern countries. This article was written within the context of constructivism and feminist international relations theory.
\end{abstract}

\section{Keywords}

Political Women, Constructivism, Personality, Experiences, Political Environment

\section{Introduction}

The ancient Roman political system evolved through time. From 753-509 B.C. monarchies dominated the people of Rome. Roman citizens led by Publius Valerius and Lucius Brutus overthrew the tyrannical monarchy of Tarquinius Superbus in 509 B.C. and established a republic. Internal and external strife and civil wars led to the emergence of Caesar Augustus as emperor in 27 B.C. By 117 the Roman Empire extended from the rugged highlands of Scotland to the hot desert of Arabia. The empire encompassed two million square miles, 44 provinces, and 40 million people which made it too large to govern from one capital (Mommsen, 1996). The division of the empire became permanent in 364 with the rule of Valentinian I from Rome and Flavius Valens from Constantinople 
(Threadgold, 1995).

The Western Roman Empire collapsed in 476 when Odoacer, a powerful Germanic king, deposed Emperor Romulus Augustulus at Rome. The Eastern Roman Empire continued to thrive, although in time it underwent significant cultural changes. The culture which emerged included the Greek language which became the official language on all government documents by the seventh century, the emergence of the Eastern Orthodox Church, combined with Asian features and characteristics. However, the Eastern Empire preserved many customs and traditions of the Western Empire and continued to consider themselves as Romans (Goffart, 1980). Meanwhile Western Europe became an unstable mosaic of Germanic kingdoms. In order to reestablish order, stability and the rule of law in the West, in 800 Pope Leo III crowned Charlemagne, king of the Franks as Emperor of the Romans. This paved the way for the creation of the Holy Roman Empire in 962 with a German King, Otto I as its first emperor. The empire encompassed a varying complex of lands in Western and Central Europe. The Eastern Roman Empire comprised Asia Minor and south Balkan Peninsula (King, 1969).

\section{Review of the Literature}

Unfortunately, there are few primary source materials which cover the reign of Yolanda of Flanders. The best primary source is: and Georgius Acropolitae, Corpus Scriptorum Historiae Byzantinae. Useful secondary sources include Vasiliev, Alexander A., A History of the Byzantine Empire, vol. 2; Longnon, Jean., L'Empire latin de Constantinople et la princippaute de Moree (Longnon, 1949), who presents the entire history of the Latin Empire, while Threadgold, Warren, A History of the Byzantine State and Society, offers the entire history of the Byzantine Empire. An excellent source for the late medieval Balkans is Fine, John, The Late Medieval Balkans: A Critical Survey from the Late Twelfth Century to the Ottoman Conquest (Fine, 1987). Agathias Scholasticus wrote a history of the Eastern Roman Empire from 552-559. Additional sources will be cited, archaeological evidence explored, and coins, portraits and busts of Yolanda examined.

\section{Scope and Method}

The methodology employed in this paper is a configurative-ideographic case study based on a biographical Sketch of Yolanda of Flanders within the political realities of the Byzantine Empire during the $11^{\text {th }}$ century, and constructivism and feminist international relations theory. This is a topic that needs addressing for two reasons. The first reason is to better understand the ascent of a Latin-speaking woman from Western Europe as potentate of an Eastern political system despite Byzantine differences with the West in religion, language and cultural norms. The second reason is to inquire whether or not gender is a systematic social construction that impedes the political ambition of women or if class matters more than constructivism and feminist international relations 
theory (Harding, 1987). It is important to increase understanding of how gender is constructed and functions in social, cultural, historical, and institutional contexts, particularly as they affect political leadership roles for women.

\subsection{The Eastern Roman Empire (Byzantine Empire)}

In 330 the Roman Emperor Constantine I (285-337) founded a new capital of the Roman Empire on the site of an ancient Greek city named Byzantium. He recognized the need for a capital to replace Rome, which was losing the ability to serve as the center of defense for the widely spread frontiers on the Rhine and Danube rivers and in the East (Eusebius, 1999). Throughout its history the empire experienced dissensions, court intrigues and corruption. Foreign invaders often tried to subdue parts or all of Byzantium. It boundaries shifted according to military fortunes, the strength of the enemies and vigor of the central authority in Constantinople. In 797 Irene Irene Sarantapechaina (752-803) (Irene of Athens) (Irene the Athenian) became the first women potentate of the Roman Empire. She served in this capacity from 797-802. This was a major breakthrough for women. No woman in the Western Roman Empire had served as emperor. However, at least one woman served in the Roman Senate of the Western Empire. Her name was Julia Symiamira) (Julia Soaemias Bassiana (180-222). She was appointed to the Senate by Emperor Antoninus Heliogabalus (Elagabalus) (203-222). She issued "decrees of the Senate... dealing with laws applying to married women" (Aelius, 1976). The Vestal Virgins who served in the Western Empire had considerable authority in religious and moral matters. They also handled secret documents and legal wills and could grant immunity to criminals (Wildfang, 2006).

What factors allowed Irene to become the first woman emperor of the Roman Empire? In a de jure sense, during the lifetime of the reigning emperor his/her successor was chosen by the Senate and the Patriarch of Constantinople crowned the new emperor upon his succession. In a de facto sense succession was dynastic in nature. There are three reasons for her ascendancy. The first reason is that she belonged to the patrician class, was very wealthy, socially prominent, and popular. For these reasons Emperor Constantine V (741-775) chose her as a bride for his son Leo IV. The second reason was that Irene exemplified the virtue of piety well, and piety was a virtue especially esteemed for the women of Rome. The third reason for the ascendance of Irene was her talent for leadership. She was energetic, productive and adaptable. Theophanes (759-818), an ecclesiastic, wrote that Irene was "most pious, ambitious and possessed a brave and prudent mind" (Theophanes, 2006). Threadgold, Warren also praises Irene's character and leadership: She had "keen political instincts, a strong will, and some devoted allies in the bureaucracy... She relied heavily on her civil officials and clergy... the results served the empire rather well (1997). In the final analysis, Irene ascended to the throne through the support of powerful men and women of that time (Belfiglio, 2013). 
After the reign of Irene there was a continued expansion of the Byzantine Empire. A series of expansions of the imperial frontiers occurred in the Balkans, Asia, Minor, Syria, Armenia, Italy and the Mediterranean Islands. The Abbasid Caliphate was the most dangerous threat. An unfortunate event occurred in 1054 when conflicting perspectives regarding icons led to a permanent schism between the Roman Catholic Church and the Eastern Orthodox Church. The main cause of the hostility was rivalry for church control. This rivalry exacerbated the conflict between Rome and Constantinople as to successor status of the Roman Empire. In Addition, the rise of the Seljuk Turks in 1048 posed a serious threat to Byzantine lands (Haldon, 2001). During the period 1042-1056 two sisters emerged as potentates of the Byzantine Empire.

Zoe (978-1050) and Theodora (980-1056) Porphyrogenita were born in Constantinople. They were the daughters of Emperor Constantine VIII and his wife Helena. Constantine served as emperor from 1025-1028. There were no male heirs to the throne, therefore, as the eldest daughter, Zoe became empress and married Romanos III Argyros, the urban prefect of Constantinople on November 10, 1028 and became rulers of the empire. Zoe and Theodora's' professional careers were in imperial politics. Zoe served as regent or co-emperor to five emperors between 1028 and 1050, and as emperor in 1042. Theodora co-reigned with two emperors and as sole ruler of the empire from 1055-1056 (Psellus, 1953). The sisters managed the empire well, although Psellus wrote: "the nations around us have made their sudden incursions against our borders and the army and fleet were downsized" (Psellus, 1953; Belfiglio, 2016).

During the interval between the rule of Theodora and Yolanda of Flanders (1217-1219) the Eastern Roman Empire became weakened by a series of setbacks. During the Battle of Manzikert (1071) the army of Seljuk Turks under the command of Sultan Alp Arslan defeated the army of Emperor Romanus IV Diogenes and captured Romanus in the process. The defeat and capture of the emperor demonstrated that the Eastern Roman Empire was fallible and could be defeated. The Turks also seized Jerusalem in 1071. Through wars with the Turks, Normans, civil wars, internal chaos, rebellions among the themata, and the Crusades the empire began to disintegrate. Bulgaria steadily increased its power during the ninth and tenth centuries and became a major player in the region. By 1203 Turks seized land in Anatolia while the Bulgars ravaged lands in the European provinces (Psellus, 1953; Haldon, 2001). To make matters worse, the Holy Roman Empire and Byzantine Empire continued to become more polarized and adversarial.

The Fourth Crusade (1202-1204) had a devastating adverse effect on the Eastern Roman Empire. Pope Innocent III called upon Christendom to undertake a new effort of regain Jerusalem from Moslem control. Venice, a republican city-state rose to become a major maritime power during the $11^{\text {th }}$ century. The Venetians and France led a large Western coalition eastward. They favored territorial aggrandizement over religious motives. The Crusaders led by Marquis 
Boniface of Montferrat conquered Zara in 1202 and Constantinople in 1204. They then divided the spoils with Venice and established the Latin Empire of Constantinople. An oligarchy comprised of six Crusader and six Venetian barons chose Count Baldwin of Flanders as Emperor Baldwin I of Constantinople (1204-1205). Emperor Baldwin received a quarter of both Constantinople and the empire as his domain. Three other leaders established empires at Nicaea, Trebizond and the on shores of Bithynia and Paphlagonia (Georgius, 1937). In 1217 the Latin barons elected Peter II of Courtenay (1155-1217) as Emperor. However, Peter became missing in action during a battle near Dyrrhachium with the forces of Theodore Ducas of Epirus. Since the empire was still dynastic in nature, Peter's wife Yolanda became emperor of Constantinople in 1217 (Georgius, 1937).

\subsection{Empress Yolanda: A Biographical Sketch}

Yolanda of Flanders (Yolande de Hainault) (Violante) (Jolanta) (Iolanda) (1175-1219) became the first woman, Latin potentate of the Roman Empire. She was the daughter of Baldwin V, Count of Hainault, and Countess Margaret of Flanders. During this period Flanders was a part of the Holy Roman Empire, which was then ruled by Emperor Frederick II of the House of Hohenstaufen. Yolanda was born in Hainault in 1175. Two of her brothers, Baldwin I (1204-1206) and Henry (1206-1216) were emperors in Constantinople. Although the date of their marriage is unclear, Peter and Yolanda had ten children. Two of them, Robert of Courtenay (1221-1228) and Baldwin II of Constantinople (1228-1261) served as emperor. Although nothing is recorded about Yolanda's education it can be assumed by her station that she was tutored by a leading scholar. In contrast to the religion of most citizens of Constantinople, who belonged to the Eastern Orthodox Church, Yolanda was a Roman Catholic. Yolanda was Marchioness of Namur (1212-1217), which she inherited from her brother, Marquis Philip I, in 1212 and left to her eldest son, Marquis Phillip II, when she went to Constantinople in 1216. Namur was an important trading center, located at the confluence of the Sambre and Meuse rivers. Yolanda also ruled as regent of the Eastern Roman Empire from 1217-1219. As such she exercised plenipotentiary powers (Georgius, 1937).

Yolanda became regent of Constantinople at a most difficult time. Her reign depended upon a series of unstable alliances within and without the empire. In addition, the Eastern Empire faced the potential threat of foreign invasions by the Turks and Arabs. In 1217 a Crusade against the sultanate of Egypt failed, and in 1218 Genghis Khan conquered Persia. What was the nature of the character of the empress who faced such daunting tasks? Unfortunately, ancient writers have not given us a profile of Yolanda and we can only speculate from her actions. In July 2009 I visited the Byzantium Display saloon of the Istanbul Archaeology Museum in Istanbul, Turkey. The museum has a large portrait of Yolanda by an unknown artist. In the portrait Yolanda wears an orange and blue silk kirtle with 
a navy-blue cape decorated with silver studs and a silver clasp at the top. The empress grasps a scepter in her left hand which she holds close to her body. Her right arm is raised with the palm of the hand slightly open. Yolanda's displays a simple smile with rose-red lips, and gentle features beneath a jeweled crown, long dark hair and large brown eyes. My overall impression is that the artist is depicting Yolanda as the embodiment of the Roman virtue of pietas, as readiness to perform duty towards god, the state and the family.

Yolanda had no known military experience. She employed diplomatic means to maintain the integrity of the empire and protect it from foreign invaders. She maintained an alliance with Boril of Bulgaria established in 1214. However, Ivan Asen II defeated the army of Boril in a Civil War in 1218 and the new regime was less friendly to the Latin Empire (Georgius, 1937). Yolanda then moved to secure an alliance with Theodore I Laskaris, emperor of Nicaea. Laskaris married Yolanda's daughter Marie of Courtenay in 1218 (Nicol, 2002). Yolanda died at Constantinople in 1219 of unknown causes. A gold coin (aureus) containing her likeness was minted in Constantinople c. 1218-1219. The coin portrays Yolanda dressed in full, regal attire. Surrounding the figure are the words: Basilissa Iolanda (Empress Yolanda, in Greek). The back side of the coin features a likeness of the Hagia Sophia, a Christian church at Constantinople. Written there are the words: "Nova Roma" in Greek. The coiner gives the impression of Yolanda as straightforward, dignified, correct and unpretentious. Yolanda's eldest son, Philip refused the unstable Latin throne after her death, and her succession passed to her second son Robert of Courtenay in 1221 (Threadgold, 1997).

\section{United States Presidential Election of 2016}

What can be extrapolated from this study about the loss of Secretary Hillary Clinton to President Donald Trump? There are many theories about this matter, from a Russian conspiracy to poor campaigning. Clinton won 2.86 million more votes than Trump, yet Trump won the presidency by receiving 306 electoral votes to Clinton's 232 electoral votes. What is clear is that Trump's victory was due in part to the peculiarity of the American Electoral College system. What is less clear is that Trump fulfilled the virtue of pietas to a greater extent than Clinton. Throughout the history of Western Civilization mysticism and religion have always been associated with women in some form. Examples are the influence of the Oracle of Delphi in ancient Greece and the Chief Vestal Virgin in ancient Rome. In modern America Evangelicals, the Christian Coalition and other devout Christians favor political leaders who avow a deep belief in Christianity and its doctrines. President Trump was a strong supporter of Christianity, the family and the state. Yolanda and the other three empresses of the Eastern Roman Empire were devout Christians. Secretary Clinton's campaign stressed devotion to family and the state but did not sufficiently emphasize the importance of the Christian God. The Secular Progressive agenda of which she is a part was perceived by many devout Christians as adversarial to their faith. This factor 
has not have been sufficiently addressed by scholars who analyze the election of 2016. Of course, this is only one of the many factors which should be taken into account. Other women leaders in the West such as Prime Ministers Margaret Thatcher (1979-1990) and Theresa May (2016-) and Chancellor Angela Merkel (2009-) stressed sufficient devotion to Christianity to become elected to Heads of Government, following the examples of the four Roman empresses. Margaret Thatcher's father was a Methodist local preacher and raised his daughter as a strict Wesleyan Methodist. Theresa May's father was a vicar and Theresa is a devout member of the Anglican Church. Angela Merkel's father was a Lutheran Clergyman and she a devout member of the Lutheran Church (Beckett, 2006; Prince, 2017; Skard, 2014).

\section{Conclusion}

Sometimes great leaders can alter the course of history, while other leaders are entrapped by history. Yolanda belonged to the latter group. Nothing in the literature suggests that she actively sought to become potentate of the Eastern Roman Empire. The death of her husband and the virtue of pietas placed her in this position. No books or scholarly articles have been written about her, yet she served as empress during a difficult time in Byzantine history. She appears to have been a relatively receptive, passive person who desired to maintain the stability of the empire through agreement and support from others. The findings of this study challenge the theory that constructivism or gender determines the role of women within a political system. The collective experiences of Empresses Irene, Zoe, Theodora and Yolanda suggest that class and political connections are more important than social construction and gender in determining the rise of women to high political office. Women at the higher end of the social stratum have a significant advantage over women and men at the lower end of the social stratum.

\section{References}

Acropolitae, G. (1937). Annales Corpus Scriptorum Historiae Byzantinae (Translated by Valentine J. Belfiglio). Bonn: Webber.

Aelius, L. (1976). 5.2. Antonius Heliogabalus. In Anthony Birley, Lives of the Later Caesars (p. 293). New York: Penguin Books. (Lampridius was one of the six Scriptores of Historia Augusta.)

Beckett, C. (2006). The 20 British Prime Ministers of the 20th Century (pp. 1-16). London: Haus.

Belfiglio, V. (2013). Irene of Athens: First Woman Potentate of the Roman Empire. The International Journal of Interdisciplinary Civic and Political Studies, 8, 1-7. https://doi.org/10.18848/2327-0071/CGP/v07i01/53136

Belfiglio, V. (2016). When Two Sisters Jointly Ruled an Empire. Sociology Study, 6, 410-416.

Eusebius (1999). Life of Constantine (3.47, pp. 4-53, Translated by Cameron, Averil and Hall, Stuart G.). Oxford: Clarendon Press. 
Fine, J. (1987). The Late Medieval Balkans: A Critical Survey from the Late Twelfth Century of the Ottoman Conquest. Ann Arbor.

Goffart, W. (1980). Barbarians and Romans: The Techniques of Accommodation (pp. 211-230). Princeton, NJ: Princeton University Press.

Haldon, J. (2001). The Byzantine Wars (pp. 67-108). Charleston, SC: Tempus.

Harding, S. (1987). Introduction: Is There a Feminist Methodology? In S. Harding (Ed.), Feminism and Methodology (pp. 1-14). Bloomington, IN: Indiana University Press. https://doi.org/10.1520/STP20024S

King, H. C. (1969). A History of Civilization (pp. 179-192, 257-262). New York: Charles Scribner's Sons.

Longnon, J. (1949). L'Empire Latin de Constantinople et la princippaute de Moree. Paris: Muse.

Mommsen, T. (1996). The Provinces of the Roman Empire (Vol. II, Chapter IX). New York, NY: Barnes \& Noble.

Nicol, D. M. (2002). The Last Centuries of Byzantium. Cambridge: Cambridge University Press.

Prince, R. (2017). Theresa May: The Enigmatic Prime Minister (pp. 16-30). London: Biteback.

Psellus, M. (1953). The Chronographia. Translated by Sewter, E.R., London: Routledge.

Scholasticus, A. (1975). The Histories. Translated by Joseph D. Frendo, New York, NY: Walter De Gruyter.

Skard, T. (2014). “Angela Merkel," in Women in Power (pp. 1-24). Bristol.

Theophanes (2006). The Chronicles of Theophanes Confessor: Byzantine and Near Eastern History: AD 284-813 (Translated by Mango, Cyril and Scott, Roger). Oxford: Clarendon Press.

Threadgold, W. (1995). Byzantium and Its Army: 284-1081 (pp. 8-14). Stanford, CA: Stanford University Press.

Threadgold, W. (1997). A History of the Byzantine State and Society. Stanford, CA: Stanford University Press.

Vasiliev, A. A. (1952). A History of the Byzantine Empire (Vol. 2). Cambridge, WI: University of Wisconsin Press.

Wildfang, R. L. (2006). Rome's Vestal Virgins: A Study of Rome's Vestal Priestesses in the Late Republic and Early Empire (pp. 64-74). London: Routledge. 